\title{
KINERJA HORMON REPRODUKSI DAN TINGKAT ABNORMALITAS LARVA IKAN NILA (OREOCHROMIS NILOTICUS LINNAEUS 1758) YANG DIPAPAR LIMBAH CAIR KELAPA SAWIT (PKPT-Tahun Pertama dan Kedua)
}

TKT

Targer akhir Tingkat Kesiapterapan Teknologi (TKT) untuk penelitian ini berada pada tingkat 3.
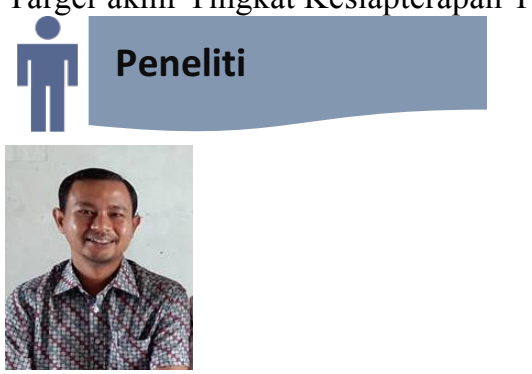

Muliari, S.Kel, M.Si NIDN: 0123078602

Universitas Al Muslim Muliari86@gmail.com

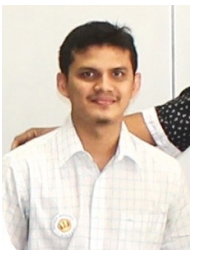

Ilham Zulfahmi, S.Kel, M.Si NIDN: 1316078801

Universitas Islam Negeri Ar-Raniry Ilhamgravel@yahoo.com

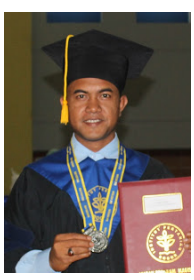

drh.Yusrizal Akmal, M.Si NIDN: 1322018701 Universitas Al Muslim drh.yusrizal.akmal.msi@gmail.com

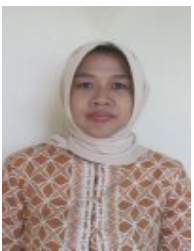

drh. Ni Wayan Kurniani Karja, MP, Ph.D NIDN: 0007026902

Institut Pertanian Bogor

karjanwk13@gmail.com

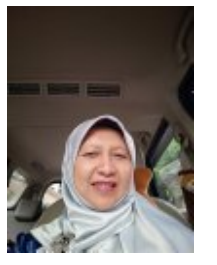

Dr. drh. Chairun Nisa', M.Si, PAVet NIDN: 0025116307

Institut Pertanian Bogor

chnisa@yahoo.com

\section{Pendahuluan}

Limbah cair kelapa sawit merupakan salah satu hasil samping dari pengolahan kelapa sawit yang berpotensi mencemari lingkungan terutama lingkungan perairan (Singh et al., 2011). Menurut Madaki dan Seng (2013), sebanyak 2.5 ton limbah cair kelapa sawit akan dihasilkan dari setiap ton proses pengolahan minyak kelapa sawit. Salah satu dampak negatif yang ditimbulkan dari industri pabrik kelapa sawit adalah timbulnya berbagai masalah lingkungan, terutama lingkungan aquatik. Penelitian PKPT tahun pertama menganalisis efek negatif dari limbah cair kelapa sawit yang berpotensi menganggu kinerja hormon reproduksi, mengalami kerusakan gonad, insang dan hati (Zulfahmi et al., 2017; Muliari et al., 2018; Zulfahmi et al., 2018; Muliari et al., 2019). Penelitian PKPT tahun kedua ini bertujuan menganalisis dampak limbah cair kelapa sawit terhadap kehidupan larva ikan nila. Rancangan penelitian terdiri dari empat perlakuan dengan lima ulangan untuk masing-masing perlakuannya: kontrol (0 mg/L), Perlakuan A (1.565 mg/L), Perlakuan B (2.347 mg/L), dan Perlakuan C $(3.130 \mathrm{mg} / \mathrm{L})$. Hasil Penelitian tahun pertama 2018 mengungkapkan bahwa paparan limbah cair kelapa sawit menyebabkan terjadi penurunan konsentrasi hormon ekstradiol, progresteron dan testosteron pada ikan nila, sehingga berdampak pada meningkatnya abnormalitas larva ikan Nila (Oreochromis niloticus). Hasil penelitian tahun kedua 2019 menunjukkan bahwa paparan limbah cair kelapa sawit memiliki dampak negatif menurunkan daya tetas dan kelangsungan hidup serta meningkatkan abnormalitas dan detak jantung larva ikan nila.

Kata kunci: Reproduksi, hormon, abnormalitas larva, detak jantung

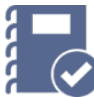

\section{HKI dan Publikasi}

Muliari et al. 2019. Effects of Palm Oil Mill Effluent on Reproductive Hormone of Female Nile Tilapia, Oreochromis niloticus (Linnaeus 1758) (accepted).

Muliari et al. 2018. Histopathological changes in gill of Nile tilapia (Oreochromis niloticus) after palm oil mill effluent exposure (IOP Conference Series: published)

Muliari et al. 2019. Toxicity of Palm Oil Mill Effluent on Nile Tilapia (Oreochromis niloticus, Linnaeus 1758) Early Life Stages, toxicology report, (submitted).

Muliari et al. 2019. Effect of exposure to palm oil mill effluent on reproductive impairment of male Nile Tilapia (Oreochromis niloticus, Linnaeus 1758) (E3S Web of Conferences: accepted)

Muliari et al. 2019. Ekotoksikologi Akuatik. IPB Press, Bogor (published) 


\section{Metodelogi}

Sebanyak 2.400 butir telur ikan nila yang telah dibuahi (fertilized eggs) dikoleksi dari Balai Perikanan Budidaya Air Payau (BPBAP) Ujong Batee, Kabupanten Aceh Besar, Provinsi Aceh, sedangkan limbah cair kelapa sawit diperoleh dari Pabrik Kelapa Sawit (PKS) yang berlokasi di Kabupaten Bireuen, Provinsi Aceh. Sampai dengan masa pemaparan limbah cair kelapa sawit disimpan pada suhu minus 19 ${ }^{\mathrm{O}} \mathrm{C}$ untuk menghindari degradasi. Secara rinci deskripsi setiap perlakuan yaitu Kontrol $(0 \%$ limbah cair kelapa sawit: $0 \mathrm{mg} / \mathrm{L}$ ), Perlakuan A $\left(10 \%\right.$ dari nilai $\left.96-\mathrm{h} \quad \mathrm{LC}_{50}: 1.565 \mathrm{mg} / \mathrm{L}\right)$, Perlakuan B $\left(15 \%\right.$ dari nilai $96-\mathrm{h} \mathrm{LC}_{50}: 2.347$ $\mathrm{mg} / \mathrm{L})$, dan Perlakuan C (20\% dari nilai $96-\mathrm{h}$ $\mathrm{LC}_{50}: 3.130 \mathrm{mg} / \mathrm{L}$ ). Daya tetas larva pada setiap perlakuan diamati setiap 24 jam. Daya tetas komulatif, laju malformasi dan panjang larva ditentukan berdasarkan persamaan Zhang et al., (2016). Kelangsungan hidup, panjang larva, detak jantung dan laju malformasi diukur pada akhir masa pemaparan.

\section{Hasil dan Pembahasan}

Hasil penelitian menunjukkan bahwa nilai Telur ikan nila mulai menetas pada hari kedua hingga hari ketiga masa pemaparan. Persentase daya tetas tertinggi terdapat pada kontrol sedangkan nilai terendah terdapat pada perlakuan $\mathrm{C}$ yaitu masing-masing sebesar 93.62 $\pm 6.22 \%$ dan $75.16 \pm 9.71 \%$. Analisis statistik menunjukkan perbedaaan yang signifikan antara daya tetas pada perlakuan control dengan perlakuan $\mathrm{B}$ dan perlakuan $\mathrm{C}$ baik pada hari kedua maupun ketiga $(p<0.05)$. Hasil analisis statistik menunjukkan penurunan yang signifikan antara sintasan pada perlakuan control dengan perlakuan B dan perlakuan C $(p<0.05)$. Rendahnya daya tetas diduga terjadi akibat adanya gangguan terhadap kinerja enzim chorinase, gangguan pada fase embriogenesis serta kurangnya kemampuan larva dalam merusak cangkang telur. Chorionase adalah enzim proteolitik yang dihasilkan oleh embrio ikan berfungsi untuk merusak membran chorion terutama saat proses penetasan (Sumon et al., 2019).

Panjang total larva pada setiap perlakuan di akhir masa pemaparan berkisar antara $10.97-11.42 \mathrm{~mm}$. Hasil statistik menunjukkan tidak terdapat perbendaan yang signifikan pada panjang larva antar perlakuan.

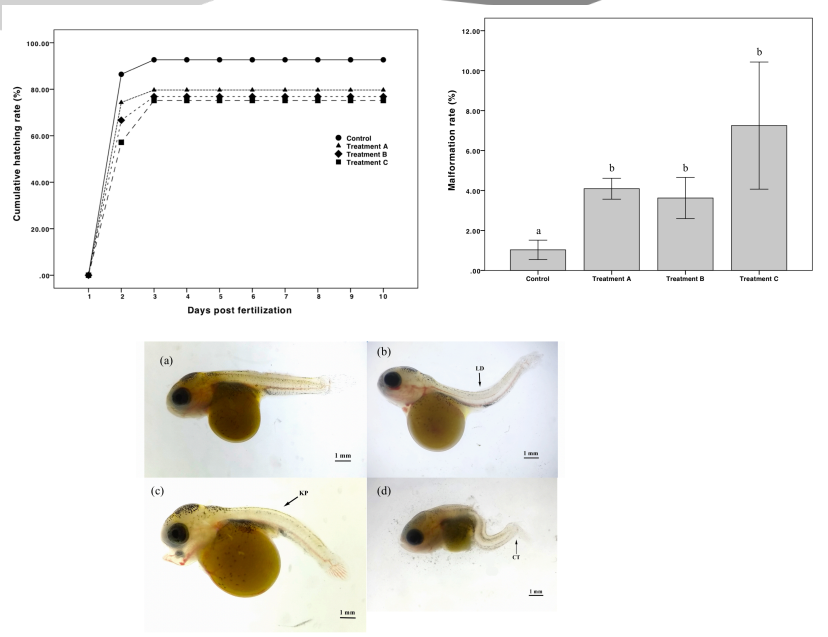

Gambar 1. Dampak paparan limbah cair kelapa sawit terhadap daya tetas komulatif ikan nila, laju malformasi ikan nila (a) Larva normal; (b) Lordosis (LD); (c) Kyphosis (KP); Pembengkokan ekor/curved tail (CT).

Sebaliknya, terjadi peningkatan detak jantung yang signifikan pada perlakuan B dan C). Detak jantung larva ikan nila pada perlakuan kontrol adalah $94.92 \pm 11.6$ detak/menit sedangkan pada perlakuan $\mathrm{B}$ dan $\mathrm{C}$ meningkat masing masing sebesar $113.35 \pm 8.91 \mathrm{detak} /$ menit dan $117.90 \pm 9.50 \mathrm{detak} / \mathrm{menit}$. Le Bihanic et al. (2014) mengungkapkan terdapat korelasi yang kuat antara tingkat abnormalitas jantung dengan turunnya detak jantung yang terpapar Polisiklik Aromatik Hidrokarbon (PAH).

Terdapat tiga bentuk abnormalitas larva yang ditemukan dalam penelitian ini yaitu lordosis, kiposis dan pembentukan ekor. Laju malformasi larva tertinggi terdapat pada perlakuan D sedangkan terendah terdapat pada perlakuan kontrol. Hasil analisis statistik menunjukkan laju malformasi larva meningkat secara signifikan pada perlakuan $\mathrm{A}, \mathrm{B}$ dan $\mathrm{C}$ dibanding dengan kontrol $(p<0.05)$. Houck dan Cech (2004) mengungkapkan adanya gangguan terhadap kinerja enzim dan hormon, penurunan imunitas serta kurangnya serapan nutrisi pada larva yang terpapar polutan.

Toksisitas limbah cair kelapa sawit menyebabkan larva ikan nila mengalami stress, yang berdampak pada meningkatnya detak jantung sebagai respon kebutukan alokasi energi yang lebih tinggi untuk kepentingan detoksifikasi. Adanya paparan polutan menyebabkan gangguan terhadap kinerja enzim tersebut yang berdampak pada menurunnya serapan oksigen selama proses embriogenesis dan mengurangi kemampuan larva untuk keluar dari cangkang telur (Girardi et al., 2017). 


\section{Kesimpulan}

Hasil penelitian PKPT tahun pertama menunjukkan bahwa paparan limbah cair kelapa sawit berdampak negatif menurunkan konsentrasi hormon estradiol dan testosteron ikan nila betina. Pada Ikan nila Jantan, paparan limbah cair kelapa sawit berakibat pada menurunnya konsentrasi hormon progresteron. Terdapat korelasi positif antara menurunnnya kadar lemak pada hati dengan menurunnya kadar lemak pada gonad.

Hasil penelitian PKPT tahun kedua menunjukkan bahwa paparan limbah cair kelapa sawit memiliki dampak negatif menurunkan daya tetas dan kelangsungan hidup serta meningkatkan abnormalitas dan detak jantung larva ikan nila. Sebaliknya, paparan limbah cair kelapa sawit tidak berdampak signifikan terhadap pertumbuhan panjang larva ikan nila. Penelitian lebih lanjut diperlukan dalam rangka memahami mekanisme fisiologis toksisitas limbah cair kelapa sawit yang menyebabkan rendahnya daya tetas telur ikan nila

\section{Daftar Pustaka}

Girardi FA, Bruch GE, Peixoto CS, Dal Bosco L, Sahoo SK, Gonçalves CO, Barros DM (2017). Toxicity of single-wall carbon nanotubes functionalized with polyethylene glycol in zebrafish (Danio rerio) embryos. Journal of Applied Toxicology 37: 214-221.

Houck A, Cech JJ (2004) Effects of dietary methylmercury on juvenile Sacramento blackfish bioenergetics. Aquatic Toxicology 69:107-123.

Le Bihanic F, Morin B, Cousin X, Le Menach K, Budzinski H, Cachot J (2014) Developmental toxicity of PAH mixtures in fish early life stages. Part I: adverse effects in rainbow trout. Environmental Science and Pollution Research 21: 13720-13731.

Madaki YS, Seng L (2013) Palm oil mill effluent (POME) from Malaysia palm oil mills: waste or resource. International Journal of Science, Environment and Technology 2: 1138-1155.
Muliari, Akmal Y, Zulfahmi I, Juanda R, Karja NWK, Nisa C (2018). Histopathological changes in gill of Nile Tilapia (Oreochromis niloticus) after palm oil mill effluent exposure. IOP Conference Series: Earth and Environmental Science 216: 1-5

Muliari, Zulfahmi I, Akmal Y, Karja NWK, Nisa C, Sumon KA (2019) Effects of palm oil mill effluent on reproductive hormone of female nile tilapia, Oreochromis niloticus (linnaeus 1758). Adv. Anim. Vet. Sci. 7: 1035-1041.

Singh RP, Embrandiri A, Ibrahim MH, Esa, N (2011) Management of biomass residues generated from palm oil mill: Vermicomposting a sustainable option. Resources, Conservation and Recycling 55: 423-434.

Sumon KA, Yesmin MF, Van den Brink PJ, Bosma RH, Peeters ET, Rashid H (2019) Effects of long-term chlorpyrifos exposure on mortality and reproductive tissues of Banded Gourami (Trichogaster fasciata).Journal of Environmental Science and Health Part B: 1-11.

Zhang QF, Li YW, Liu ZH, Chen QL (2016) Exposure to mercuric chloride induces developmental damage, oxidative stress and immunotoxicity in zebrafish embryoslarvae. Aquatic Toxicology 181: 76-85.

Zulfahmi I, Muliari, Y Akmal (2017). Indeks hepatosomatik dan histopatologi hati ikan nila (Oreochromis niloticus linnaeus 1758). Prosiding SEMDI-UNAYA (Seminar Nasional Multi Disiplin Ilmu UNAYA) 1: 301- 314 .

Zulfahmi I, Muliari, Akmal Y, Batubara AS (2018) Reproductive performance and gonad histopathology of female Nile Tilapia (Oreochromis niloticus Linnaeus 1758) exposed to palm oil mill effluent. The Egyptian Journal of Aquatic Research 44: 327-332. 